\title{
On the Structure of a Hybrid Fern.
}

\author{
BY \\ J. BRETLAND FARMER, M.A., \\ Fellow of Magdalen College, Oxford, and Professor of Botany in the \\ Royal College of Science, London.

\section{With Plates XXIII and XXIV.}

THE Fern which forms the subject of the present 1 communication, Polypodium Schneideri, was first raised at Messrs. Veitch's, Chelsea, by Mr. Schneider several years ago, and he has several times succeeded in producing it afresh. The two parents were $P$. aureum, and a variety of $P$. vulgare known as elegantissimum. The latter plant occurs wild in some parts of Cornwall, and it shows some tendency to revert, in the form of its leaves, to the common $P$. vulgare type. The spores from the varietal leaf-form were sown, and when mature prothallia had been secured, they were planted along with prothallia from $P$. aureum. This method had to be adopted on account of the very different rates of development of the gametophyte in the two species respectively, that of $P$. aureum being relatively very rapid.

I may say that I have had a conversation on the subject of the Fern with Mr. Schneider himself, who kindly showed

[Annals of Botany, Vol. XI. No. XLIV. December, 1897.] 


\section{Farmer.-On the Structure of a Hybrid Fern.}

me his extensive collection of plants at the Chelsea Nurseries, and I have no doubt whatever as to the genuine hybrid nature of the Fern, both on the ground of what I saw there, as well as on account of the strong evidence in its favour furnished by the comparative study of its anatomy. The results of the successive fresh raising of the hybrid were strikingly uniform, the intermediate characters being prominent in all.

In the robust habit of growth and in its thick and densely ramentose rhizome, the hybrid approximates far more closely to the character of $P$.aureum than to that of $P$.elegantissimum ${ }^{1}$, which possesses, relatively speaking, a slender rhizome which is not specially densely clothed with scales. Again, the presence of these ramenta (although but sparsely scattered) on the rachis of the young fronds of $P$. aureum, and, though in a less degree, on those of $P$. Schneideri also, appears in marked contrast with the naked leaf-stalk of the other parent. And this is the more singular inasmuch as in other respects the general appearance of the frond of the hybrid, save in its far larger size, very closely resembles that of $P$. elegantissimum, and is not at all like that of $P$. aureum.

It has been said that $P$.elegantissimum shows a tendency to 'revert ${ }^{2}$ ' to the simpler form of $P$. vulgare, and the same peculiarity is manifested in its bastard offspring. Sometimes only a few pinnae, or even a half-pinna, may exhibit the 'reversion' (P1. XXIV, Figs. I7, I 8); sometimes it extends to all the leaves on a branch (Fig. I9), and I saw a number of plants obtained from cuttings of such branches which had grown and remained true. But the greater number of reverted fronds of the hybrid were not quite like those of the $P$. vulgare type. Some of them exhibited the bluish bloom, and others the peculiarly wavy texture so characteristic of $P$. aureum. It was in the general outline that the

1 I use the curtailed form of the name for the sake of brevity.

2 The use of the terms 'revert' and 'reversion' is merely one of convenience, and is not intended as implying an expression of opinion on the general questions of atavistic or discontinuous variations. 
$P$. vulgare parentage was most strongly pronounced. The differences, inter se, of these reverted fronds is, I conceive, one of special interest, as affording a striking illustration of the unstable character of the hybrid.

Turning to the internal structure of the stem and of the petiole, we find a close approximation, though not a complete resemblance, between $P$. Schneideri and $P$. dureum.

The rhizome is almost exactly alike in the two cases, if one makes due allowance for a certain disparity of size. In both forms the vascular system is more complex, and the steles are larger than are those in $P$. elegantissimum.

In the leaf-stalk of $P$. Schneideri the preponderance of aureum characters is clearly marked, though in a less degree than in the rhizome. Thus an average-sized frond of $P$. aureum was found to possess, at the base of the stalk, two large steles beneath the adaxial face, together with four or five small ones, the whole group being disposed in a circle, as is shown in Pl. XXIII, Figs. I, 2, 3. The number of the small steles varies irregularly at different heights of the petiole, owing to the frequent anastomoses and repeated divarications which occur amongst them. On the other hand, the course of the two large adaxial steles is very regular. They run in a nearly parallel direction up the leaf-stalk, only fusing at a short distance below the region of the lamina. As regards $P$. elegantissimum, the petiole possesses a far less complex vascular system. At the base, two large adaxial steles can be seen, accompanied usually by one but sometimes by two very much attenuated strands, corresponding to the four or five subsidiary steles of $P$. aureum. At a very short distance up the stalk, however, the two larger strands can alone be seen, and these fuse together about halfway up the petiole (Pl. XXIII, Fig. 5). An inspection of Figs. I- 8 on Plate XXIII will serve better than a description to illustrate the much greater approximation of $P$. Schneideri to $P$. aureum, as regards its vascular system, than to its other parent. The two large steles fuse rather earlier in the hybrid, and the number of the subsidiary 


\section{Farmer.-On the Structure of a Hybrid Fern.}

strands is, on the average, rather less and their size is smaller, than in $P$. aureum.

It is not a valid objection to the legitimacy of instituting these comparisons to urge that the degree of vascular complexity and development is merely conditioned by the size and luxuriance of the organ concerned. Of course these factors proximately determine whether large or small channels shall be sufficient, but they do not necessarily affect the particular method of arrangement, or the relative proportions existing between the various constituent strands.

Turning to the sclerenchyma which occurs at the periphery of the leaf-stalk, it is seen that in this particular also the hybrid more closely resembles one parent ( $P$. aureum) than the other. The band is, however, a little thicker, relatively to the diameter of the transverse section in P. Schneideri, and the cells are somewhat more strongly lignified. In this they approach $P$. elegantissimum, in which the band is proportionately far more highly developed, its cells are longer and are dovetailed between each other more effectively, and are both more thickened and lignified than in $P$. aureum.

As the leaf-blades of $P$. Schneideri and $P$. elegantissimum more nearly resemble each other, a considerable degree of similarity might be looked for in their epidermal cells and stomata. The resemblance as a matter of fact is fairly close (Pl. XXIII, Figs. IO, II), but there are obvious differences of detail. Thus the epidermal cells of the hybrid are a little larger, although not nearly as large as those of $P$. aureum (Fig. 9), but the guard-cells of the stomata closely resemble the guard-cells of the last-mentioned plant, save in their smaller size.

The roots of the three Ferns show a complete series of gradations, those of the hybrid standing, on the average, exactly halfway between the thin ones of $P$. elegantissimum and the much thicker ones of $P$. aureum. But the degree of variation in the detailed structure of the individual roots of even one specimen renders these organs less suitable than 
the rest for our present purpose, and they will not be further considered here.

Turning now to the sporangia, I have already alluded to the dimorphic character of the leaves in both $P$. elegantissimum and $P$. Schneideri. In the former Fern the sori are found far more abundantly on the plain than on the dissected fronds, and, when plain pinnae occur on a dissected frond, the sori are far more abundant on the uncut portions (Pl. XXIV, Fig. 15a); still the sporangia of both leaf-forms produce germinable spores, and indeed it was from spores of these dissected leaves that the parent prothallia were grown. In the case of $P$. Schneideri, however, it is rare to find sporangia upon the dissected leaf at all, and when they do occur they are quite barren. Mr. Schneider tells me he has never succeeded in raising any prothallia from them, and his statement is borne out by the fact that in all the specimens I was able to examine I found the spores degenerated. The abortion frequently does not become apparent until the spore-mother-cell, or even the tetrad, stage is reached; but in any case the mature sporangium only contains a granular mass resembling a heap of angular composite starch-grains.

In marked contrast to the scarcity of sporangia on the normal fronds of $P$. Schneideri stands their extreme abundance on the reverted leaves; even any odd pinna of a normal frond which exhibits a plain instead of a cut outline is commonly crowded with sori (P1. XXIV, Fig. I8). And yet it is quite certain that the majority at any rate of these sporangia are sterile. Some appear, notwithstanding, to possess good spores, but they have not yet been successfully germinated. Mere appearance, however, forms but an unsafe guide in estimating germinating power, as is proved by the case of Adiantum Farleyense. This Fern is, on good grounds, believed to have arisen as a sport from $A$. tenerum in Barbados, and although it sometimes bears sporangia containing spores which are to all appearance good, they are said, by the best authorities competent to judge, to be incapable of germination. It is 


\section{Farmer. - On the Structure of a Hybrid Fern.}

known that vigorous sports are sometimes highly sterile, and this circumstance, coupled with the frequent luxuriance in vegetative development of sterile leaves, has given rise to a doctrine of correlation which is doubtless a neat way of expressing the facts, but which in reality leaves us exactly where we were before. It seems, however, not altogether improbable that an extended experimental study of dimorphic Fern-leaves might well prove to be one of the avenues leading to a clearer conception of the essential differences between what we at present term vegetative and reproductive activity.

Regarding the plant now under discussion from another aspect, there are some interesting points of contact between it and other hybrids, as for example the famous Cytisus Adami.

The latter, as is known, is a hybrid between the arborescent C. Laburnum and the shrubby $C$. purpureus, although it is by no means agreed as to whether it arose as a seminal or a graft hybrid. The authority for the latter origin rests chiefly on the statements made by Adam, and on the failure of all attempts to cross the two parent forms.

The $C$. Adami produces on the same plant flowers and shoots which may be roughly referred to three categories ${ }^{1}$ :-

I. The hybrid flowers, intermediate between the two parents, and often highly variable.

2. Flowers closely resembling the Laburnum, and these are commonly borne on specially vigorous shoots.

3. Shoots with flowers and leaves of the purpureus type.

Now the regular Adami flowers are sterile. The pollen is indifferent, and the ovules, according to Caspary, are monstrous and incapable of fertilization. But the two reverting forms can both set good seed from which new plants can be raised. And although the seedlings thus obtained closely resemble the parent form to which the seed-bearing shoot had reverted, it is clear that they have not purged themselves of their mixed origin, since Herbert ${ }^{2}$, while hinting at a certain

${ }^{1}$ See description (with coloured plates) by Édouard Morren in La Belgique Horticole, $187 \mathrm{I}$.

${ }^{2}$ Herbert, Journ. Hort. Soc., vol. ii. 
amount of variability amongst the purpureus lot, expressly mentions the fact that a purple colour was sometimes present on the flower-stalks of seedling-plants which otherwise would be referable to C. Laburnum. The fact that the reversion to the parent form in C.Adami is both more perfect and also seems to be accompanied by a corresponding increase in fertility, when compared with the state of things present in $P$. Schneideri, does not in any way affect the legitimacy of instituting a comparison between these two plants; but rather adds to its interest.

Although the reversion on the part of the Polypody is commonly in the direction of the vulgare type, indications are not wanting, as has already been stated, that the aureum form may also reassert itself; and in the Cytisus it is usual for one (commonly the Laburnum) parent to manifest itself before the other. The extreme sterility of the hybrid type in both cases is of special interest when contrasted with the known fertility of the reverted portions of Cytisus and their possible fertility in the Fern. Even should the spores of the latter prove not to be germinable, they are, as microscopic examination shows, far less hopelessly barren than are those on the hybrid plants, and they are immeasurably more numerous.

Of course it may be argued, as has already been hinted, that the sterility of the hybrid leaf is not necessarily a consequence of its hybrid origin, but is merely correlated with the foliar expansion, just as the leafy sterile part of an Osmunda frond is said to be when compared with its contracted fertile part. And it might be urged that, on my own showing, the dissected fronds of $P$. elegantissimum are not so sporangiferous as are those which have assimilated themselves to the vulgare type. But the first argument, even if the premises be admitted, is not to the point; and with regard to the second, it may be said that we are thereby brought no nearer to accounting for the absolutely sterile nature of the hybrid spores, whether the sori are produced in abundance or not, and this peculiarity must, I think, depend on some intimate change in the configuration or composition 


\section{Farmer.-On the Structure of a Hybrid Fern.}

of the protoplasm, and I believe we may here fairly ascribe it to the effect of the crossing. Although it may be premature to speculate on the nature of the processes concerned in the production of hybrids, I am convinced that a careful study of these organisms will do much to throw light on the obscurities of heredity, and perhaps even on the essentials of ordinary fertilization. It seems certain that the quality which we term heredity, by virtue of which organisms are what they are, and what their forbears have been before them, must either be associated with definite discrete particles, ids, which by a series of kaleidoscopic rearrangements are able to form new combinations after the manner imagined by Weismann: or else that heredity must depend on the configuration, physical and molecular, of a substance taken as $a$ whole, and its interaction with the other constituents of the cell. In the former case, with each generation a new arrangement of the pre-existent and persistent particles, each associated with hereditary qualities, is assumed to occur; in the latter case a new substance must be formed, which, by virtue of its constitution as a whole, governs and determines the mode of development of the organism. The id-theory seems irreconcilable with what we now know of the details of fertilization in plants, and at least in some animals. In these, what direct evidence we have, tells against the preliminary elimination of unlike hereditary units from the sexual cells during their course of development, and clearly indicates rather an equivalent distribution of substance. But if this is really true, even in a few cases, the objective basis of the id-theory is clearly destroyed; for the elimination of half the parental ids from each gamete previous to their union, forms an essential part of the theoretical structure built up and maintained by Weismann and his followers. The case of hybrids has been used by the exponents of the id-theory to strengthen their case, and preponderating multiplication of paternal or maternal ids - the result of an imaginary struggle between purely hypothetical combatants - is supposed to finally account for the resemblance of this or that 
cell to one or other parent; but the phenomena seem to be more readily susceptible of explanation if we assume that the hereditary substance acts as a whole, and by virtue of its own particular composition. The hereditary substance derived from two parents might equally well form a relatively stable or an unstable combination whether this depended on the nature of the molecular structure of the substance in question or on still more complex arrangement of molecular aggregates. In any case, operating, as it must, on and through the rest of the cell-contents, the results of its activity will be profoundly modified by the nature of the latter, and also, though less immediately perhaps, by such external agencies as in turn may affect them. And thus I think we may in a measure see how a plant can become materially altered in its form so as to suit different environments, without having to postulate the existence of a reserve store of emergency ids in order to explain the often extraordinary manifestation of adaptive variations which may arise within the limits of a single species or even of a single individual. In this connexion I might cite, for example, the variation of the leafform ${ }^{1}$ met with in amphibious plants. We know of many cases in which a plant will develop in a particular way as the result of stimuli which we can hardly regard as other than physical or chemical, certainly not as the result of the direct action of hereditary ids. Thus pollination is a necessary antecedent to ovule-formation in many flowers. But if it be urged that the ids are there, and only need the stimulus to excite them to activity, this explanation can scarcely be seriously urged to meet the case of galls, each form of which is peculiar to and characteristic of a special parasite reacting on a special plant. Again, in the St. Valéry apple, different forms of fruit are produced on the same tree as the result of pollination from different sources of apples. Here there can be no question as to the travelling out of the ids from the

1 Weismann has discussed the question of polymorphism (The Germ Plasm, Contemporary Science Series, I893) with the result of adding considerably to the complexity of his theory. 


\section{Farmer. - On the Structure of a Hybrid Fern.}

new generation into the sporophyte of the old, whereby a particular new form of fruit is stimulated to grow. Nor can we assume that the tree had stores of ids requisite to produce this or that form of fruit. If we say that the pollination stimulated the formation of new arrangements of ids, we are going far beyond analogies based on knowledge, which would rather suggest chemical interaction, and are simply abandoning ourselves to flights of pure fancy.

And to return to the Fern, I confess I find it almost impossible to imagine a machinery complex enough to account for the reversions it exhibits on the assumption of separate ids, whilst it does not, to me at least, seem so unintelligible on the alternative view. Instances might easily be multiplied. Thus Hildebrand ${ }^{1}$ found, in a cross between Oxalis latifolia and $O$. tetraphylla, that the characteristically distinct hairs of each species might both arise from a single epidermal cell of the offspring. Are we in this case to imagine that the ids and determinants of the corresponding cells in both parents were all actively present in the nucleus of this epidermal cell? And if we answer in the affirmative, how shall we explain the further case that amongst the offspring obtained by crossing $O$. lasiandra with $O$. Andreuxii, some of the hybrids possessed flowers readily distinguishable from those of either parent, not only on account of their larger size, but also in their totally different colour? What, we may ask, has become of the action of the individual ids here? The frequently observed sterility of hybrids, as well as the failure of numerous likely crosses to set seed, may be due, quite as well as to an unsuitable consorting of ids, to the imperfect combination or union of the parental substances, a defect the results of which (whatever its true nature may be) are apparent in all degrees and gradations varying from positive and absolute sterility on the one hand and only stopping short of actual fertility on the other.

These are only tentative suggestions, for in the present

\footnotetext{
${ }^{1}$ F. Hildebrand, Ueber einige Pflanzenbastardierungen; Jen. Zeitschr., Bd. 23, 1889 .
} 
Farmer.-On the Structure of a Hybrid Fern. 543

condition of our knowledge we can only grope about after a clue to the solution of the problems before us-a clue which recent cytological work seems to have shown us to be less accessible than we had previously hoped. But I do not believe they are really unsoluble; they demand, however, experimental treatment on the part of botanists such as they have already begun to receive at the hands of comparative physiologists, and it behoves cytologists not to neglect such means of assistance as a careful study of the structure and origin of hybrids, in the garden as well as in the laboratory, is able to provide.

\section{EXPLANATION OF FIGURES IN PLATES XXIII AND XXIV.}

Illustrating Professor Farmer's paper on the Structure of a Hybrid Fern.

[Figs. I-I 3, camera lucida drawings, Zeiss $A \times 2$ oc. (the figures I-9 reduced to $\left.\frac{1}{2}\right)$. Figs. I4-19, photographs, $\frac{1}{7}$ natural size.]

Figs. I, 2, 3. Sections of the petiole of Polypodium aureum.

Fig. I. Transverse section through the base of the petiole, showing peripheral band of sclerenchyma, scl., and the steles, two large and five small ones. $e$. endodermis ; $P$. pericycle; $p h$. phloem; $x y$. xylem.

Fig. 2. Section a little below the middle of the petiole. Shows anastomosis between the smaller steles.

Fig. 3. Section a little below the region of the lamina of the leaf.

Fig. 4. Section through the base of the petiole of Polypodium vulgare, var. elegantissimum.

Fig. 5. Section taken through the same petiole at $\frac{1}{3}$ the distance between the base and the insertion of the lowest pinna.

Figs. 6, 7, 8. Sections through the petiole of Polypodium Schneideri, taken from regions corresponding with those of $P$. aureum in Figs. I-3.

Fig. 9. Epidermis from the lower surface of the leaf of Polypodium aureum.

Fig. Io. Epidermis from the lower surface of the leaf of $P$. vulgare, var. elegantissimum.

Fig. I I. Epidermis from the lower surface of the leaf of P. Schneideri.

Fig. 12. Sporangium (showing barren contents) from dissected frond of P. Schneideri. 


\section{Farmer.-On the Structure of a Hybrid Fern.}

Fig. I3. Sporangium from 'reverted' frond of the same fern.

Fig. I 4. Leaf of $P$. aureum (under side).

Figs, I5, I5 $a$. Two leaves of $P$. vulgare, var. elegantissimum. Both show 'reverted' pinnae.

Fig. I6. Normal frond of P. Schneideri (under surface).

Fig. I 7. Partially 'reverted' leaf of same (upper surface).

Fig. 18. Under surface of a similar leaf. Sporangia abundant on 'reverted' parts.

Fig. 19. Completely 'reverted' leaf of the same. Sporangia very abundant. 

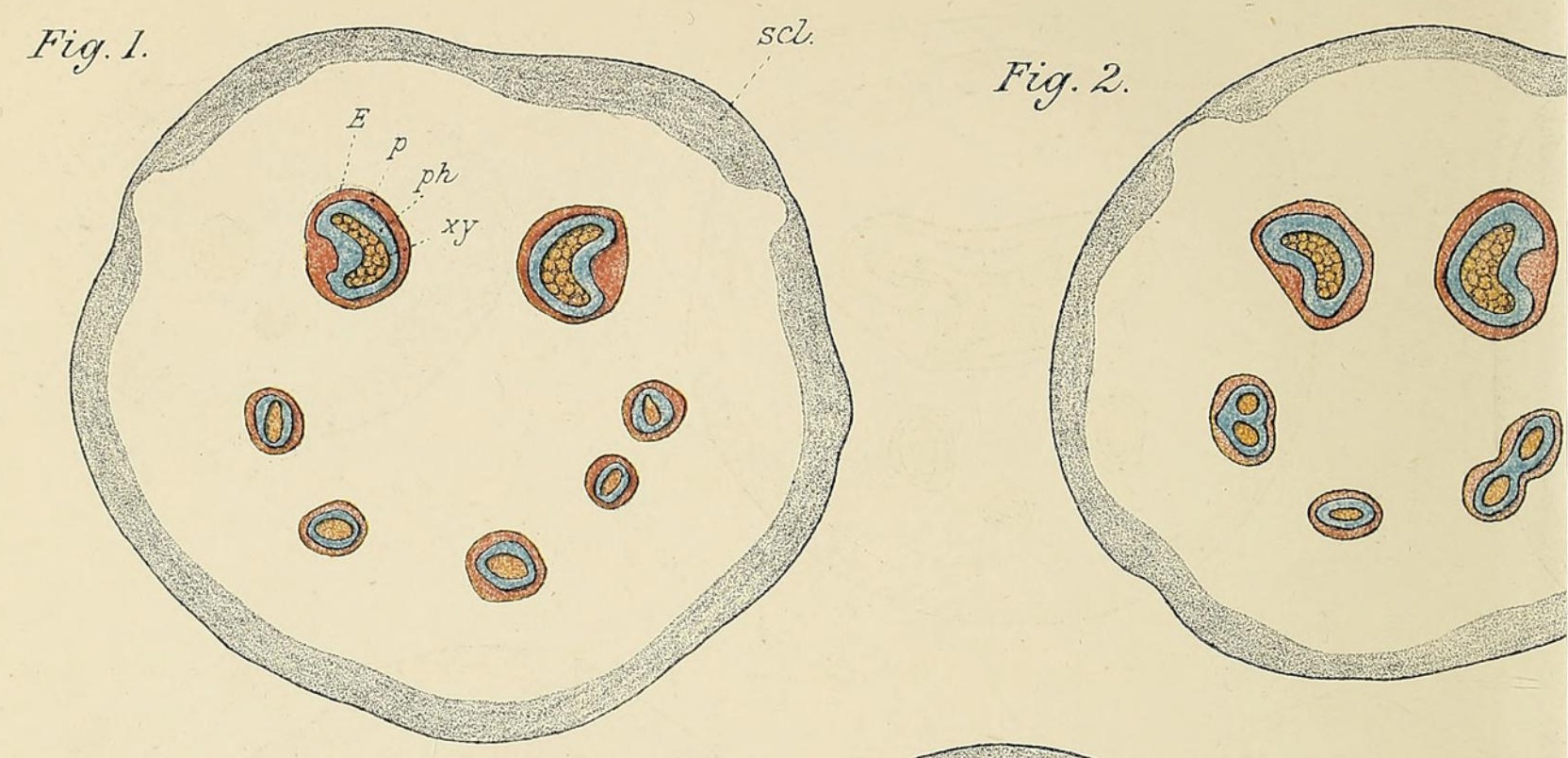

Fig. 5.
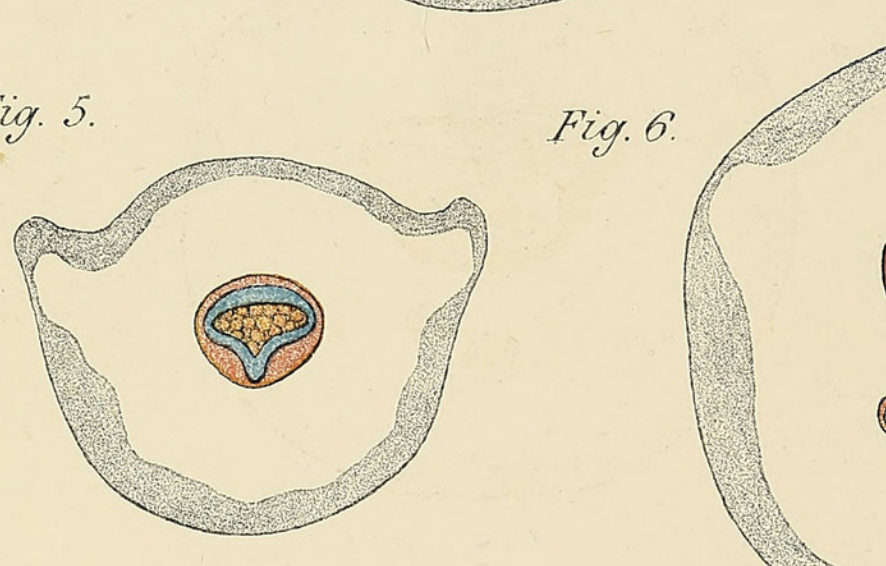

Fig. 6.

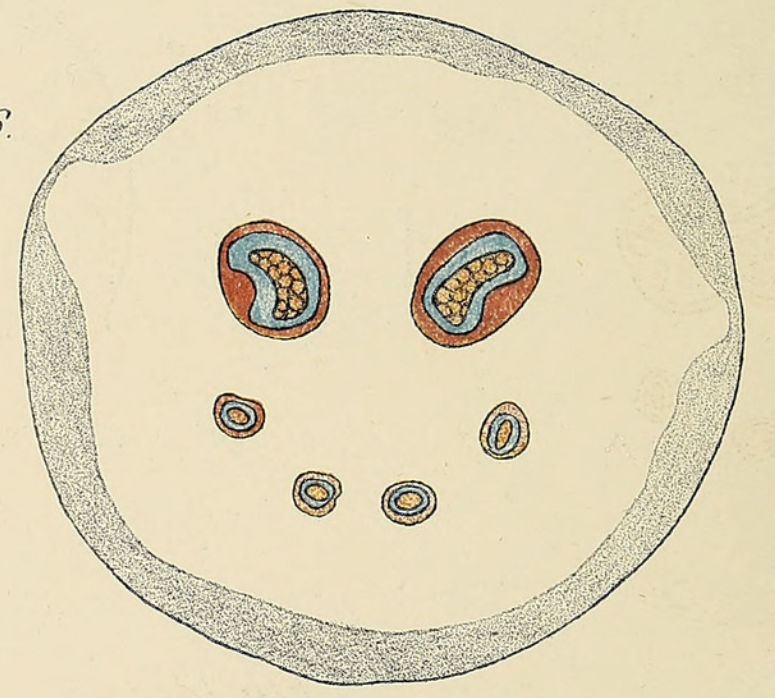

Fig. $\%$

Fig.9.
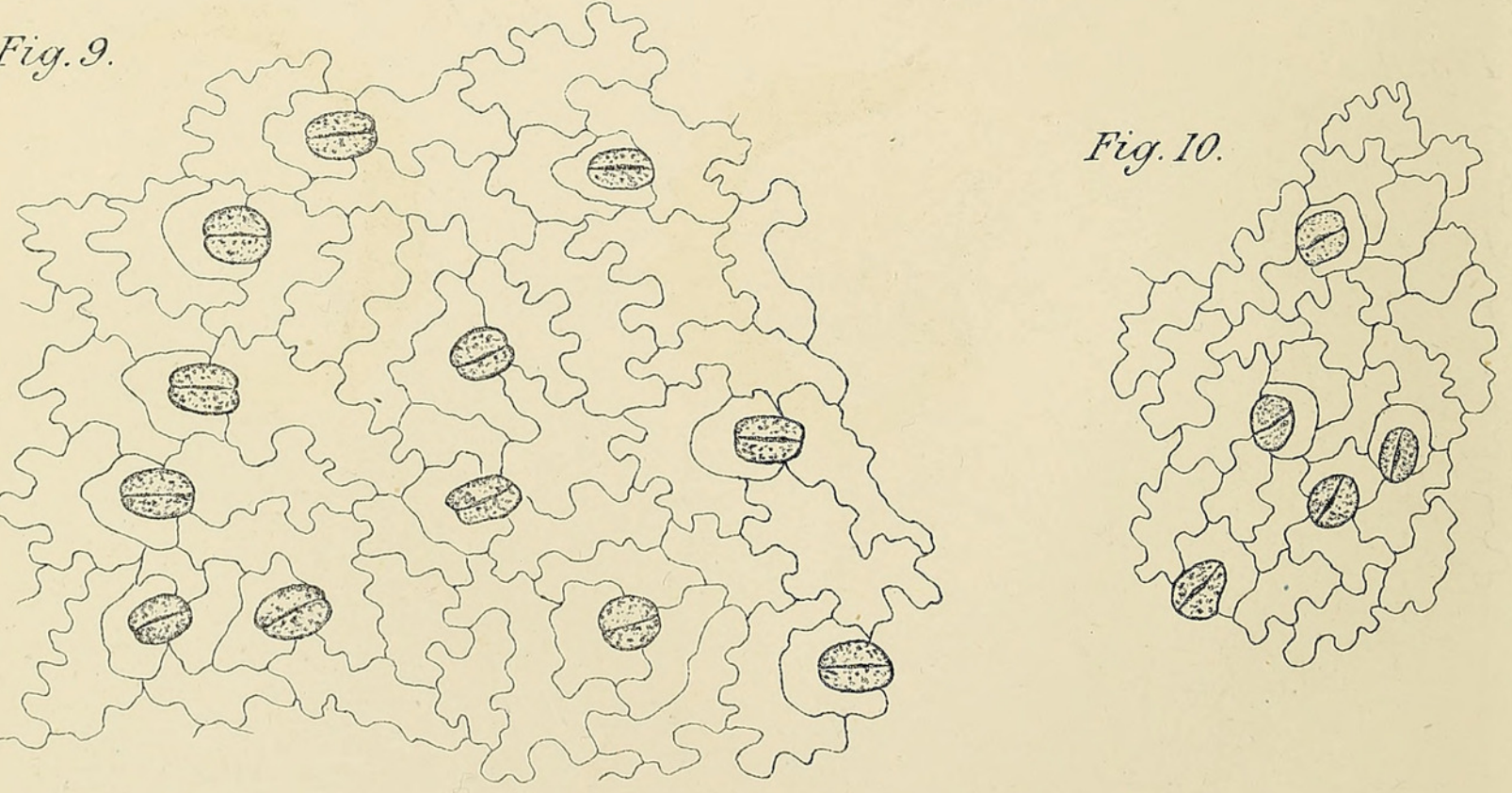


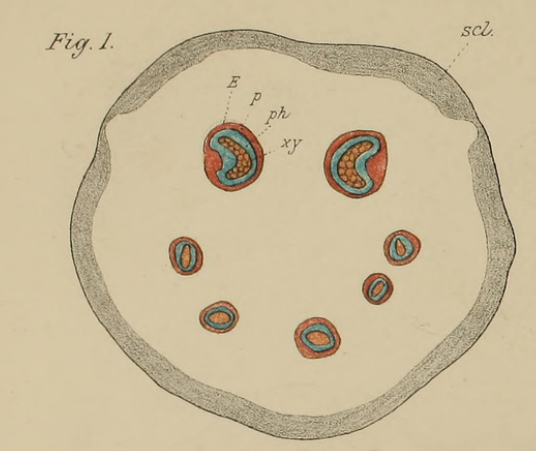

Fig. 5.

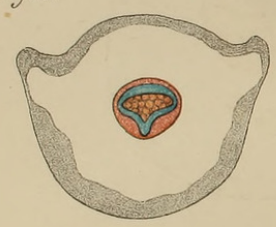

Fig. 6.
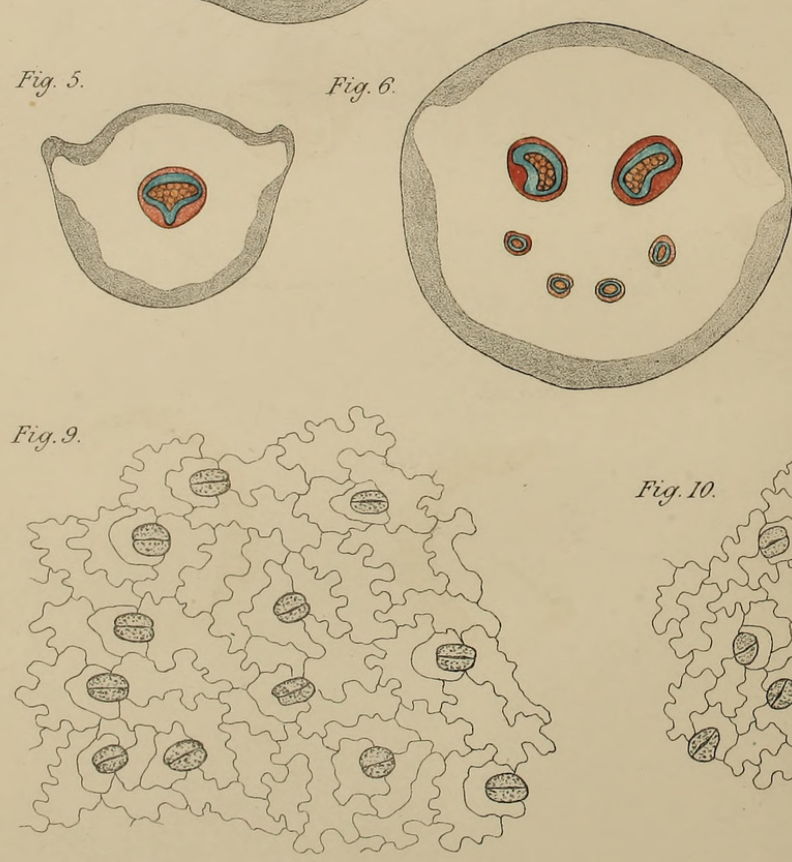
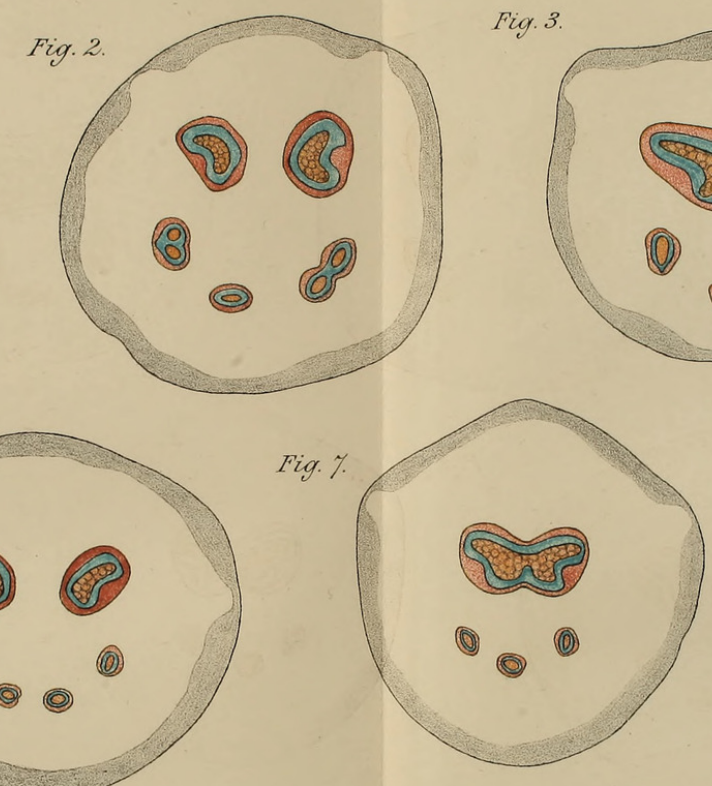

Fig. II.

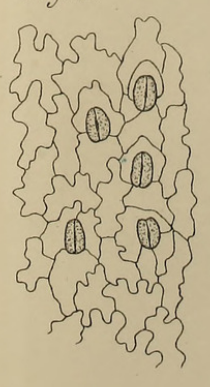

Fig. 3.

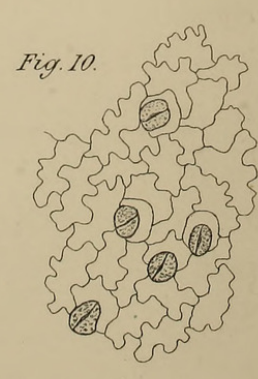

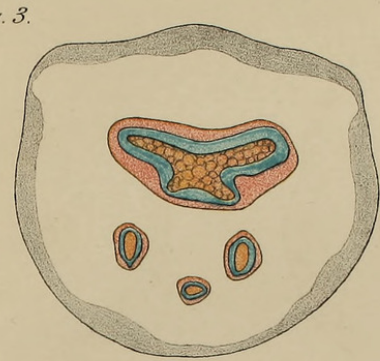

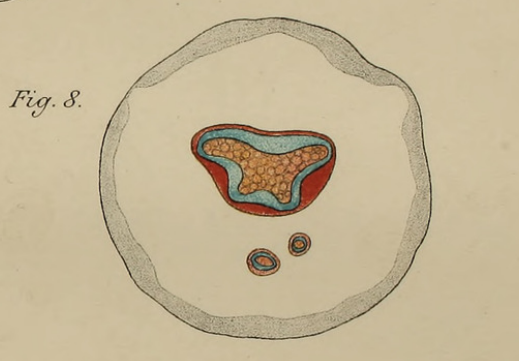

Fig. 12.

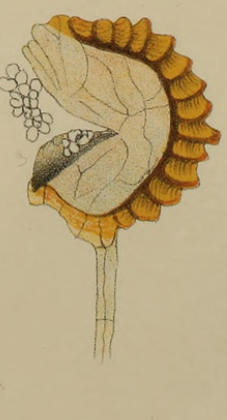

Fig. 4.

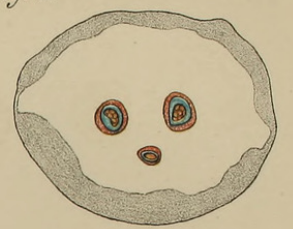



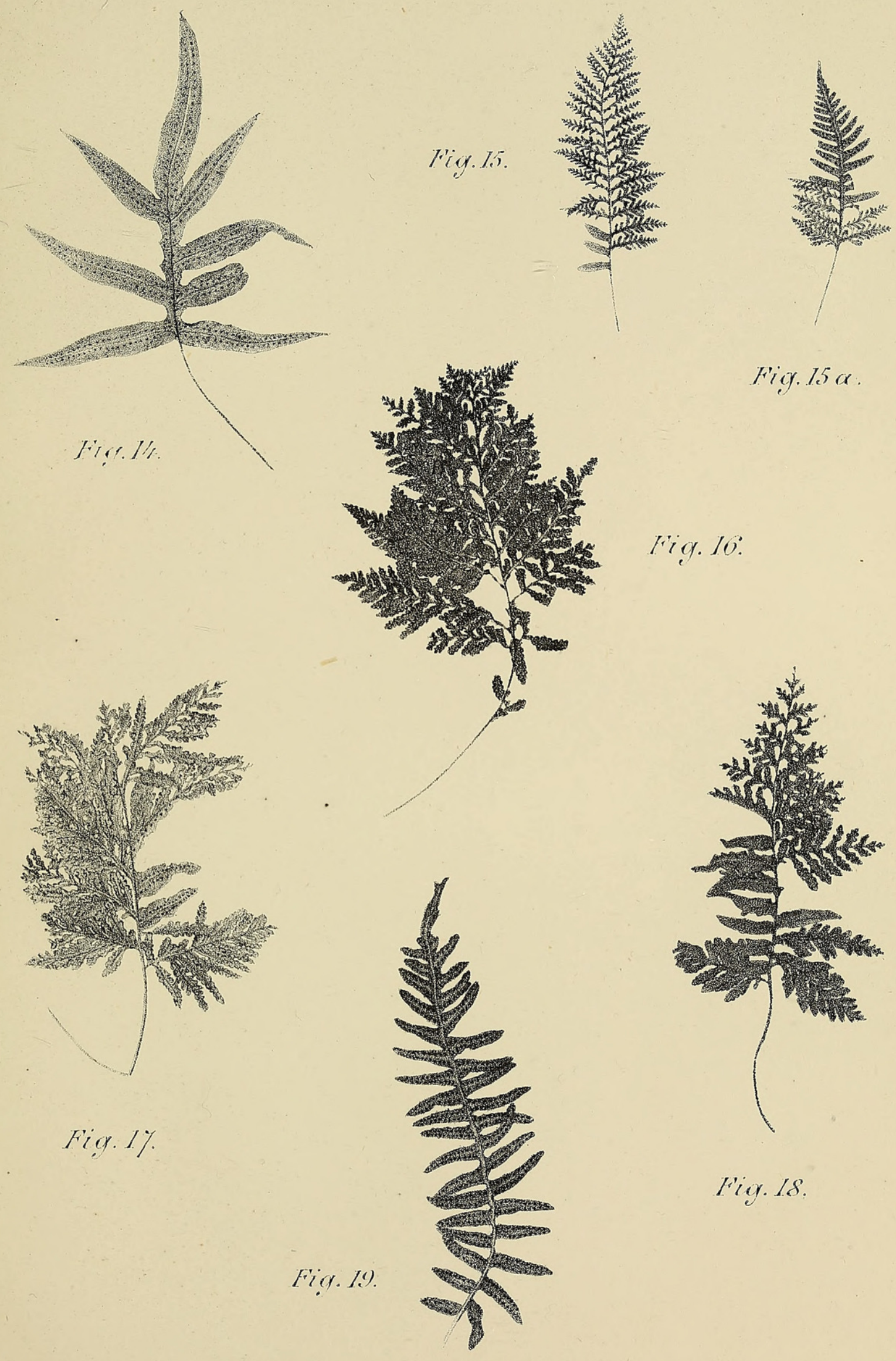

Fig. $15 \alpha$

Fig. 10

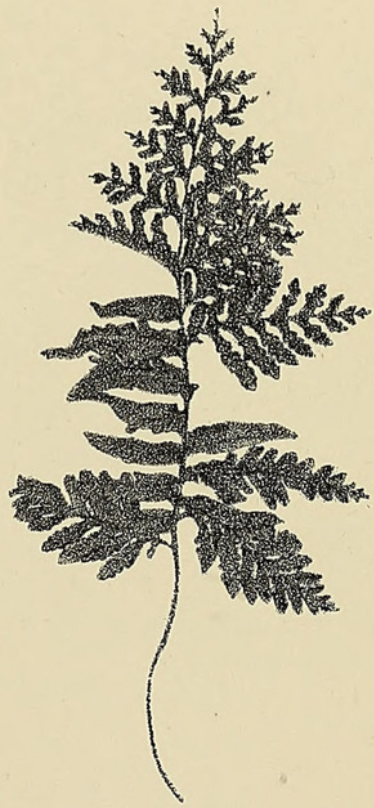

Figr. 18 . 


\section{$2 \mathrm{BHL}$ Biodiversity Heritage Library}

Farmer, J. B. 1897. "On the structure of a hybrid fern." Annals of botany 11, 533-544. https://doi.org/10.1093/oxfordjournals.aob.a088669.

View This Item Online: https://www.biodiversitylibrary.org/item/233542

DOI: https://doi.org/10.1093/oxfordjournals.aob.a088669

Permalink: https://www.biodiversitylibrary.org/partpdf/318481

\section{Holding Institution}

Smithsonian Libraries

\section{Sponsored by}

Biodiversity Heritage Library

\section{Copyright \& Reuse}

Copyright Status: Not in copyright. The BHL knows of no copyright restrictions on this item.

This document was created from content at the Biodiversity Heritage Library, the world's largest open access digital library for biodiversity literature and archives. Visit BHL at https://www.biodiversitylibrary.org. 